\title{
Językowy obraz kobiety w prasie dla pań (na przykładzie „Zwierciadła”, „Przyjaciółki” i „Cosmopolitan”)
}

Przedmiotem tego artykułu jest zaprezentowanie językowego obrazu kobiety we współczesnej prasie dla pań.

Moim zainteresowaniem objęte zostały dwa luksusowe magazyny: „Zwierciadło" i „Cosmopolitan” oraz jedno pismo poradnikowe - „Przyjaciółka”. Wyboru tego dokonałam, opierając się na trzech najistotniejszych (z punktu widzenia analizy społeczno-ekonomicznej) przesłankach. Pierwszą z nich był target, druga - okres obecności na polskim rynku medialnym, trzecią- pozycja zajmowana na tymże rynku. Zebrałam wszystkie wymienione przeze mnie tytuły pism opublikowane od grudnia 2006 do lutego 2008 roku (po 15 numerów „Zwierciadła” i „Cosmopolitan” oraz 45 numerów „Przyjaciółki”). Dokonując ekscerpcji materiału językowego, zajęłam się skrupulatnie kilkoma numerami (,Zwierciadło” - numery 4, 5, 8 z roku 2007; „Cosmopolitan” - numery 2, 4, 8, 9 z roku 2007 oraz „Przyjaciółka” - numer 50/51 z roku 2006, numery 11, 21, 40, 41, 49 z roku 2007 oraz numery 4, 5 z roku 2008). W ten sposób dokładną analizą objęłam ponad 550 stron każdego z czasopism. Z pozostałych numerów wybrałam po $10 \%$ ich zawartości (w przypadku: „Zwierciadła” - 18 stron, „Cosmopolitan” - 15 stron, „Przyjaciółki” - 6 stron). Liczba wybranych przeze mnie stron została dokładnie obliczona z uwzględnieniem częstości ukazywania się periodyku oraz objętości tekstów.

Przy gromadzeniu materiału ograniczyłam się do leksemu kobieta, pomijając wszystkie jego synonimy i peryfrazy ${ }^{1}$. Wyraz ten w prasie kobiecej wy-

${ }^{1}$ Ten sam sposób pracy z materiałem dostrzec można w wielu publikacjach naukowych, m.in.: M. Karwatowska, Jezzkowy obraz „kłamstwa”, w: Jezzyk w kręgu wartości. Studia semantyczne, red. J. Bartmiński, Lublin 2003, s. 319-337; E. Sękowska, Językowy obraz ciata $w$ prasie ostatnich lat, w: Polszczyzna $w$ komunikowaniu publicznym. Prace poświęcone 
stępuje najczęściej w określonych obszarach tematycznych. Zgodnie z nimi udało mi się wyróżnić dwanaście profili² porządkujących materię językowego obrazu kobiety zawartego w badanych pismach. Dla precyzyjniejszego usystematyzowania bazy materiałowej w obrębie każdego z profili wyróżniłam od kilku do kilkunastu podkategorii - faset (tab. 1).

Dyskusyjna może się wydawać obecność profilu pierwszego. Otóż umieściłam tu wszelkie użycia leksemu kobieta, w których semantyce mieści się wyraźnie wskazanie na płeć i istotę kobiecości. Użycia te trudno było przypisać jakiejkolwiek innej kategorii, nie wskazywały one bowiem niczego poza przynależnością płciową. Nie oznacza to oczywiście, że te poświadczenia leksemu kobieta mają status nienacechowany - nienaznaczony językowym obrazem kobiety. Każde użycie tego słowa uruchamia językowy obraz świata. By jednak ten językowy obraz świata poznać, musimy skupić się na analizie wszystkich pozostałych profili - zebrane w nich ekscerpty pozwalają bowiem na formułowanie konkretnych wniosków. Dzięki tym wnioskom zrozumiemy, jaki obraz kobiety uruchamia użycie leksemu kobieta, pozornie wskazującego jedynie na płeć.

W każdej z faset znajdującej się w obrębie profili umieszczone zostały ekscerpty dotyczące cechy zasygnalizowanej w nazwie fasety oraz jej przeciwieństwo (np. atrakcyjność i nieatrakcyjność). Wyjątek stanowi wyróżnienie dwóch odrębnych faset w profilu szóstym - ,aktywność, zaradność, pomysłowość, siła” oraz jej przeciwieństwo - „,bierność, bezradność, apatia”, ze względu na zasadniczą odmienność obu cech i ich niecałkowitą antonimię.

Dodać też należy, że niektóre ekscerpty ze względu na fakt, iż dotyczyły różnych sfer tematycznych, zostały przyporządkowane do więcej niż jednej kategorii tematycznej.

Opis rozpocznę od ukazania różnic ilościowych, które bez problemu można zauważyć w zebranym materiale. Mimo przyjęcia tych samach ograniczeń liczbowych w „Zwierciadle” odnalazłam 801 ekscerptów, w „Przyjaciółce” 297, w „Cosmopolitan” natomiast - 534.

Profesor Halinie Satkiewicz z okazji jubileuszu Jej i Jej Zakładu, red. W. Gruszczyński, J. Bralczyk, G. Majkowska, Warszawa 1999, s. 69-77; M. Pietrucha, Profile pojęcia „demokracji” we wspótczesnym języku polskim, w: Język w kręgu wartości. Studia semantyczne, red. J. Bartmiński, Lublin 2003, s. 273-307; M. Nowosad-Bakalarczyk, Kobieta ,typowa” $i$,prawdziwa" w oczach studentów. Przyczynek do stereotypu kobiety, „Język Polski” 2002, nr 1, s. 25-35.

${ }^{2}$ Przy ustalaniu profili posiłkowałam się pracą L. Kaczmarka, T. Skubalanki, S. Grabiasa, Stownik gwary studenckiej, Lublin 1994. Praca nad tym artykułem wymagała jednak wprowadzenia licznych zmian oraz uszczegółowień. 
Tabela 1. Układ profili i faset porządkujących materiał językowy

\begin{tabular}{|c|c|c|}
\hline Lp. & Profil & Faseta \\
\hline 1. & Kobieta ogólnie - płeć, istota & \\
\hline 2. & Części ciała & $\begin{array}{l}\text { a) włosy } \\
\text { b) usta (uśmiech) } \\
\text { c) ręce, ramiona } \\
\text { d) piersi } \\
\text { e) brzuch } \\
\text { f) pośladki } \\
\text { g) nogi } \\
\text { h) twarz } \\
\text { i) skóra }\end{array}$ \\
\hline 3. & Ubiór & $\begin{array}{l}\text { a) odzież wierzchnia } \\
\text { b) bielizna } \\
\text { c) obuwie } \\
\text { d) elegancja, dobry wygląd }\end{array}$ \\
\hline 4. & Cechy fizyczne & $\begin{array}{l}\text { a) uroda, atrakcyjność, seksowność } \\
\text { b) budowa ciała, waga } \\
\text { c) wiek } \\
\text { d) kosmetyka, higiena osobista }\end{array}$ \\
\hline 5. & $\begin{array}{l}\text { Procesy oraz czynności fizyczne } \\
\text { i fizjologiczne }\end{array}$ & $\begin{array}{l}\text { a) mówienie, porozumiewanie się } \\
\text { b) jedzenie } \\
\text { c) spanie } \\
\text { d) płacz } \\
\text { e) śmierć } \\
\text { f) stan zdrowia fizycznego } \\
\text { g) ciąża, poród, karmienie piersią } \\
\text { h) poruszanie się, pozycja ciała } \\
\text { i) ból, cierpienie fizyczne }\end{array}$ \\
\hline 6. & $\begin{array}{l}\text { Cechy i procesy psychiczne, postawa } \\
\text { kobiety wobec otoczenia }\end{array}$ & $\begin{array}{l}\text { a) strach, obawy, zagubienie } \\
\text { b) samotność } \\
\text { c) smutek, zły humor } \\
\text { d) wstyd } \\
\text { e) radość, entuzjazm, szczęście } \\
\text { f) myślenie, zastanawianie się } \\
\text { g) marzenia, pragnienia } \\
\text { h) autoanaliza, autokrytyka } \\
\text { i) inteligencja, zdolności intelektualne } \\
\text { j) doświadczenia życiowe, przeżycia } \\
\text { k) stosunek do otoczenia } \\
\text { l) cechy charakteru } \\
\text { m) zmęczenie psychiczne } \\
\text { n) aktywność, zaradność, pomysłowość, siła } \\
\text { o) bierność, bezradność, apatia } \\
\text { p) spokój, poczucie bezpieczeństwa } \\
\text { q) uczucie wolności, emancypacja, } \\
\text { niezależność } \\
\text { r) poczucie winy } \\
\text { s) odpowiedzialność } \\
\text { t) godność, poczucie własnej wartości, } \\
\text { pewność siebie } \\
\text { u) stan zdrowia psychicznego }\end{array}$ \\
\hline
\end{tabular}


tab. $1 \mathrm{~cd}$.

\begin{tabular}{|c|c|c|}
\hline Lp. & Profile & Fasety \\
\hline 7. & Postawa otoczenia wobec kobiety & $\begin{array}{l}\text { a) pozytywna } \\
\text { b) negatywna }\end{array}$ \\
\hline 8. & Praca, finanse, nauka, wykształcenie & $\begin{array}{l}\text { a) praca, wykonywany zawód } \\
\text { b) awans, kariera } \\
\text { c) zdobyte wykształcenie } \\
\text { d) zarobki, sytuacja ekonomiczna, pozycja } \\
\text { społeczna } \\
\text { e) nauka, studia, szkoła } \\
\text { f) umiejętności, zdolności praktyczne, } \\
\text { predyspozycje }\end{array}$ \\
\hline 9. & Wypoczynek, życie kulturalne i towarzyskie & $\begin{array}{l}\text { a) urlop, wakacje } \\
\text { b) używki } \\
\text { c) imprezy, spotkania towarzyskie, taniec, } \\
\text { śpiew, gra na instrumencie } \\
\text { d) sport, gry towarzyskie }\end{array}$ \\
\hline 10. & $\begin{array}{l}\text { Życie w społeczeństwie } \\
\text { (miejskim i wiejskim) }\end{array}$ & $\begin{array}{l}\text { a) pomoc społeczna } \\
\text { b) zakupy i usługi } \\
\text { c) wspólnota, działalność społeczna } \\
\text { i polityczna }\end{array}$ \\
\hline 11. & Miłość, seks, intymność & $\begin{array}{l}\text { a) techniki erotyczne, zachowania seksualne } \\
\text { b) partner, partnerka } \\
\text { c) zdrada, rozstanie, rozwód } \\
\text { d) środki antykoncepcyjne }\end{array}$ \\
\hline 12. & $\dot{Z}$ ycie rodzinne & $\begin{array}{l}\text { a) mąż, partner życiowy } \\
\text { b) dzieci } \\
\text { c) rodzice, teściowie } \\
\text { d) dziadkowie } \\
\text { e) dalsza rodzina } \\
\text { f) prowadzenie domu }\end{array}$ \\
\hline
\end{tabular}

W „Zwierciadle” leksem kobieta występuje zdecydowanie najczęściej (49\% wszystkich zebranych przeze mnie ekscerptów). W pozostałych dwóch czasopismach pojawiał się on rzadziej - łącznie suma poświadczeń poszukiwanego leksemu w „Cosmopolitan” i „Przyjaciółce” dorównała liczebnie tym odnalezionym w samym tylko „Zwierciadle”. Jeżeli przyjąć, że - by posłużyć się pojęciem z zakresu literaturoznawstwa - głównym bohaterem każdego z wymienionych czasopism jest 'dorosła osoba płci żeńskiej', to stwierdzić należy, że jedynie „Zwierciadło” owego bohatera nazywa kobietą. Zjawisko to zasługuje z pewnością na przeprowadzenie osobnych badań. Z poczynionych obserwacji wynika jednak, że w języku „Przyjaciółki” ‘dorosła osoba płci żeńskiej' to po prostu pani (wyraz w słownikach języka polskiego traktowany jako synonim leksemu kobieta). Problem ten jest natomiast zdecydowanie bardziej skomplikowany w przypadku „Cosmopolitan”. Bohaterka jest bowiem najczęściej dziewczyna lub cosmodziewczyna, co - idąc za definicjami leksykogra- 
ficznymi - oznacza 'młodą kobietę niezamężną; pannę’3. Choć nie powinno się wyciagać zbyt daleko idących wniosków z tych w dużej mierze intuicyjnych spostrzeżeń, bardzo łatwo zauważyć, że każde z badanych czasopism stawia swoją bohaterkę (a z nią przecież utożsamia się czytelniczka) w nieco innej roli społecznej i życiowej.

Poniżej umieszczam szczegółowe dane liczbowe związane z zebranym materiałem językowym. Ekscerpty zawierające leksem kobieta przypisane zostały konkretnym profilom.

Tabela 2. Liczba ekscerptów odnalezionych w badanych czasopismach z podziałem na profile

\begin{tabular}{|c|c|c|c|c|}
\hline Lp. & Profil & Czasopismo & Ekscerpty & Suma \\
\hline 1. & Kobieta ogólnie - płeć, istota & $\begin{array}{l}\text { „Zwierciadło”, } \\
\text { „Przyjaciółka”", } \\
\text { „Cosmopolitan” }\end{array}$ & $\begin{array}{r}128 \\
35 \\
58\end{array}$ & 221 \\
\hline 2. & Części ciała & $\begin{array}{l}\text { „Zwierciadło”, } \\
\text { „Przyjaciółka” } \\
\text { „Cosmopolitan” }\end{array}$ & $\begin{array}{l}14 \\
17 \\
19\end{array}$ & 50 \\
\hline 3. & Ubiór & $\begin{array}{l}\text { „Zwierciadło”, } \\
\text { „Przyjaciółka” } \\
\text { „Cosmopolitan” }\end{array}$ & $\begin{array}{r}19 \\
4 \\
14\end{array}$ & 37 \\
\hline 4. & Cechy fizyczne & $\begin{array}{l}\text { „Zwierciadło”, } \\
\text { „Przyjaciółka”", } \\
\text { „Cosmopolitan” }\end{array}$ & $\begin{array}{l}65 \\
41 \\
54\end{array}$ & 160 \\
\hline & $\begin{array}{l}\text { Procesy oraz czynności } \\
\text { fizyczne i fizjologiczne }\end{array}$ & $\begin{array}{l}\text { „Zwierciadło" } \\
\text { „Przyjaciółka”, } \\
\text { „Cosmopolitan" }\end{array}$ & $\begin{array}{l}82 \\
59 \\
47\end{array}$ & 188 \\
\hline 6. & $\begin{array}{l}\text { Cechy i procesy psychiczne, } \\
\text { postawa kobiety wobec } \\
\text { otoczenia }\end{array}$ & $\begin{array}{l}\text { „Zwierciadło" } \\
\text { „Przyjaciółka” } \\
\text { „Cosmopolitan” }\end{array}$ & $\begin{array}{r}191 \\
38 \\
85\end{array}$ & 314 \\
\hline 7. & $\begin{array}{l}\text { Postawa otoczenia wobec } \\
\text { kobiety }\end{array}$ & $\begin{array}{l}\text { „Zwierciadło”, } \\
\text { „Przyjaciółka”", } \\
\text { „Cosmopolitan” }\end{array}$ & $\begin{array}{r}13 \\
2 \\
8\end{array}$ & 23 \\
\hline 8. & $\begin{array}{l}\text { Praca, finanse, nauka, } \\
\text { wykształcenie }\end{array}$ & $\begin{array}{l}\text { „Zwierciadło" } \\
\text { „Przyjaciółka”, } \\
\text { „Cosmopolitan” }\end{array}$ & $\begin{array}{l}66 \\
25 \\
36\end{array}$ & 127 \\
\hline 9. & $\begin{array}{l}\text { Wypoczynek, życie } \\
\text { kulturalne i towarzyskie }\end{array}$ & $\begin{array}{l}\text { „Zwierciadło" } \\
\text { „Przyjaciółka” } \\
\text { „Cosmopolitan” }\end{array}$ & $\begin{array}{r}18 \\
7 \\
15\end{array}$ & 40 \\
\hline 10. & $\begin{array}{l}\text { Życie w społeczeństwie } \\
\text { (miejskim i wiejskim) }\end{array}$ & $\begin{array}{l}\text { „Zwierciadło" } \\
\text { „Przyjaciółka”, } \\
\text { „Cosmopolitan" }\end{array}$ & $\begin{array}{r}35 \\
7 \\
6\end{array}$ & 48 \\
\hline
\end{tabular}

${ }^{3}$ Zob. np.: Dziewczyna, w: Popularny stownik języka polskiego PWN, oprac. E. Sobol, Warszawa 2003, s. 178. 
tab. $2 \mathrm{~cd}$.

\begin{tabular}{|c|c|c|c|c|}
\hline & Profil & Czasopismo & Ekscerpty & Suma \\
\hline 11. & Miłość, seks, intymność & $\begin{array}{l}\text { „Zwierciadło" } \\
\text { „Przyjaciółka" } \\
\text { „Cosmopolitan" }\end{array}$ & $\begin{array}{r}65 \\
23 \\
173 \\
\end{array}$ & 261 \\
\hline 12. & Życie rodzinne & $\begin{array}{l}\text { „Zwierciadło” } \\
\text { „Przyjaciółka” } \\
\text { „Cosmopolitan” }\end{array}$ & $\begin{array}{r}105 \\
39 \\
19 \\
\end{array}$ & 163 \\
\hline & & & RAZEM: & 1632 \\
\hline
\end{tabular}

Liczbę ekscerptów odnalezionych w „Zwierciadle”, „Przyjaciółce” i „Cosmopolitan" wraz z podziałem na profile i fasety zawiera poniższa tabela.

Tabela 3. Liczba ekscerptów odnalezionych w badanych czasopismach z podziałem na profile i fasety

\begin{tabular}{|c|c|c|c|c|c|c|c|c|}
\hline \multirow[b]{2}{*}{ Lp. } & \multirow[b]{2}{*}{ Profil } & \multicolumn{3}{|c|}{$\begin{array}{l}\text { Liczba } \\
\text { przykładów }\end{array}$} & \multirow[b]{2}{*}{ Faseta } & \multicolumn{3}{|c|}{$\begin{array}{l}\text { Liczba } \\
\text { przykładów }\end{array}$} \\
\hline & & 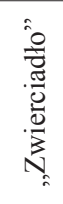 & 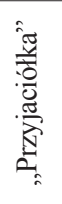 & 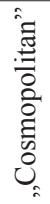 & & 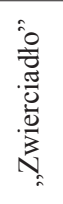 & 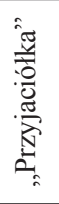 & 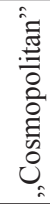 \\
\hline 1. & $\begin{array}{l}\text { Kobieta ogólnie - } \\
\text { płeć, istota }\end{array}$ & 128 & 35 & 58 & & & & \\
\hline 2. & Części ciała & 14 & 17 & 19 & $\begin{array}{l}\text { a) włosy } \\
\text { b) usta (uśmiech) } \\
\text { c) ręce, ramiona } \\
\text { d) piersi } \\
\text { e) brzuch } \\
\text { f) pośladki } \\
\text { g) nogi } \\
\text { h) twarz } \\
\text { i) skóra }\end{array}$ & $\begin{array}{l}- \\
1 \\
\overline{5} \\
2 \\
- \\
2 \\
1 \\
3\end{array}$ & $\begin{array}{l}1 \\
1 \\
1 \\
5 \\
5 \\
- \\
2 \\
- \\
2\end{array}$ & $\begin{array}{l}2 \\
- \\
1 \\
3 \\
- \\
2 \\
3 \\
1 \\
7\end{array}$ \\
\hline 3. & Ubiór & 19 & 4 & 14 & $\begin{array}{l}\text { a) odzież wierzchnia } \\
\text { b) bielizna } \\
\text { c) obuwie } \\
\text { d) elegancja, dobry wygląd }\end{array}$ & $\begin{array}{l}1 \\
5 \\
4 \\
9\end{array}$ & $\begin{array}{l}1 \\
- \\
- \\
3\end{array}$ & $\begin{array}{l}2 \\
5 \\
3 \\
4\end{array}$ \\
\hline 4. & Cechy fizyczne & 65 & 41 & 54 & $\begin{array}{l}\text { a) uroda, atrakcyjność, seksowność } \\
\text { b) budowa ciała, waga } \\
\text { c) wiek } \\
\text { d) kosmetyka, higiena osobista }\end{array}$ & $\begin{array}{r}10 \\
3 \\
38 \\
14\end{array}$ & $\begin{array}{r}9 \\
6 \\
22 \\
4\end{array}$ & $\begin{array}{r}20 \\
12 \\
14 \\
8\end{array}$ \\
\hline 5. & $\begin{array}{l}\text { Procesy oraz } \\
\text { czynności fizyczne } \\
\text { i fizjologiczne }\end{array}$ & 82 & 59 & 47 & $\begin{array}{l}\text { a) mówienie, porozumiewanie się } \\
\text { b) jedzenie } \\
\text { c) spanie } \\
\text { d) płacz } \\
\text { e) śmierć } \\
\text { f) stan zdrowia fizycznego } \\
\text { g) ciazza, poród, karmienie piersia } \\
\text { h) poruszanie sie, pozycja ciała } \\
\text { i) ból, cierpienie fizyczne }\end{array}$ & $\begin{array}{r}4 \\
4 \\
- \\
2 \\
4 \\
23 \\
40 \\
- \\
5\end{array}$ & $\begin{array}{r}- \\
3 \\
1 \\
1 \\
- \\
33 \\
21 \\
- \\
-\end{array}$ & $\begin{array}{r}5 \\
2 \\
- \\
2 \\
1 \\
23 \\
13 \\
1 \\
-\end{array}$ \\
\hline
\end{tabular}




\begin{tabular}{|c|c|c|c|c|c|c|c|c|}
\hline & $\begin{array}{l}\text { Cechy i procesy } \\
\text { psychiczne, } \\
\text { postawa kobiety } \\
\text { wobec otoczenia }\end{array}$ & 192 & 38 & 85 & $\begin{array}{l}\text { a) strach, obawy, zagubienie } \\
\text { b) samotność } \\
\text { c) smutek, zły humor } \\
\text { d) wstyd } \\
\text { e) radość, entuzjazm, szczéście } \\
\text { f) myślenie, zastanawianie się } \\
\text { g) marzenia, pragnienia } \\
\text { h) autoanaliza, autokrytyka } \\
\text { i) inteligencja, zdolności } \\
\text { intelektualne } \\
\text { j) doświadczenia życiowe, } \\
\text { przeżycia } \\
\text { k) stosunek do otoczenia } \\
\text { l) cechy charakteru } \\
\text { m) zmęczenie psychiczne } \\
\text { n) aktywność, zaradność, } \\
\text { pomysłowość, siła } \\
\text { o) bierność, bezradność, apatia } \\
\text { p) spokój, poczucie } \\
\text { bezpieczeństwa } \\
\text { q) uczucie wolności, } \\
\text { emancypacja, niezależność } \\
\text { r) poczucie winy } \\
\text { s) odpowiedzialność } \\
\text { t) godność, poczucie własnej } \\
\text { wartości, pewność siebie } \\
\text { u) stan zdrowia psychicznego }\end{array}$ & $\begin{array}{r}4 \\
4 \\
1 \\
1 \\
5 \\
3 \\
8 \\
11 \\
7 \\
\\
10 \\
\\
11 \\
20 \\
2 \\
38 \\
\\
14 \\
5 \\
\\
23 \\
\\
2 \\
2 \\
13\end{array}$ & $\begin{array}{c}- \\
- \\
1 \\
- \\
2 \\
- \\
2 \\
- \\
1 \\
8 \\
- \\
9 \\
- \\
10 \\
- \\
- \\
1 \\
- \\
2 \\
2\end{array}$ & $\begin{array}{r}- \\
3 \\
1 \\
1 \\
5 \\
- \\
1 \\
2 \\
3 \\
3 \\
3 \\
4 \\
15 \\
- \\
24 \\
1 \\
1 \\
- \\
4 \\
2 \\
\\
14 \\
2\end{array}$ \\
\hline 7. & $\begin{array}{l}\text { Postawa otoczenia } \\
\text { wobec kobiety }\end{array}$ & 13 & 2 & 8 & $\begin{array}{l}\text { a) pozytywna } \\
\text { b) negatywna }\end{array}$ & $\begin{array}{r}3 \\
10\end{array}$ & - & $\overline{8}$ \\
\hline 8. & $\begin{array}{l}\text { Praca, finanse, } \\
\text { nauka, } \\
\text { wykształcenie }\end{array}$ & 66 & 25 & 36 & $\begin{array}{l}\text { a) praca, wykonywany zawód } \\
\text { b) awans, kariera } \\
\text { c) zdobyte wykształcenie } \\
\text { d) zarobki, sytuacja } \\
\text { ekonomiczna, pozycja społeczna } \\
\text { e) nauka, studia, szkoła } \\
\text { f) umiejętności, zdolności } \\
\text { praktyczne, predyspozycje }\end{array}$ & $\begin{array}{r}30 \\
6 \\
8 \\
9 \\
\\
4 \\
9\end{array}$ & $\begin{array}{r}20 \\
1 \\
1 \\
2 \\
- \\
1\end{array}$ & $\begin{array}{r}10 \\
10 \\
2 \\
6 \\
\\
3 \\
5\end{array}$ \\
\hline 9. & $\begin{array}{l}\text { Wypoczynek, } \\
\text { życie kulturalne } \\
\text { i towarzyskie }\end{array}$ & 18 & 7 & 15 & $\begin{array}{l}\text { a) urlop, wakacje } \\
\text { b) używki } \\
\text { c) imprezy, spotkania towarzyskie, } \\
\text { taniec, śpiew, gra na instrumencie } \\
\text { d) sport, gry towarzyskie }\end{array}$ & $\begin{array}{r}- \\
1 \\
5 \\
11 \\
\end{array}$ & $\begin{array}{l}7 \\
- \\
- \\
- \\
\end{array}$ & $\begin{array}{l}3 \\
4 \\
3 \\
5\end{array}$ \\
\hline 10. & $\begin{array}{l}\text { Życie } \\
\text { w społeczeństwie } \\
\text { (miejskim i } \\
\text { wiejskim) }\end{array}$ & 35 & 7 & 6 & $\begin{array}{l}\text { a) pomoc społeczna } \\
\text { b) zakupy i usługi } \\
\text { c) wspólnota, działalność } \\
\text { społeczna i polityczna }\end{array}$ & $\begin{array}{r}8 \\
3 \\
24\end{array}$ & $\begin{array}{l}5 \\
- \\
2\end{array}$ & $\begin{array}{l}- \\
1 \\
5\end{array}$ \\
\hline 11. & $\begin{array}{l}\text { Miłość, seks, } \\
\text { intymność }\end{array}$ & 65 & 23 & 173 & $\begin{array}{l}\text { a) techniki erotyczne, } \\
\text { zachowania seksualne } \\
\text { b) partner, partnerka } \\
\text { c) zdrada, rozstanie, rozwód } \\
\text { d) środki antykoncepcyjne }\end{array}$ & $\begin{array}{r}14 \\
42 \\
9 \\
-\end{array}$ & $\begin{array}{l}6 \\
9 \\
3 \\
5\end{array}$ & $\begin{array}{l}91 \\
13 \\
13\end{array}$ \\
\hline
\end{tabular}




\begin{tabular}{|c|c|c|c|c|c|c|c|c|}
\hline \multirow[b]{2}{*}{ Lp. } & \multirow[b]{2}{*}{ Profil } & \multicolumn{3}{|c|}{$\begin{array}{c}\text { Liczba } \\
\text { przykładów }\end{array}$} & \multirow[b]{2}{*}{ Faseta } & \multicolumn{3}{|c|}{$\begin{array}{c}\text { Liczba } \\
\text { przykładów }\end{array}$} \\
\hline & & $\begin{array}{l}\hat{0} \\
\frac{0}{7} \\
. \frac{\pi}{0} \\
\frac{0}{0} \\
\frac{3}{3}\end{array}$ & 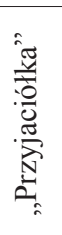 & 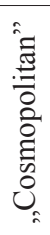 & & 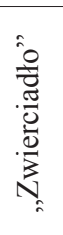 & 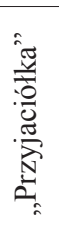 & 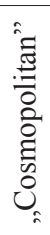 \\
\hline 12. & Życie rodzinne & 105 & 39 & 19 & $\begin{array}{l}\text { a) mąż, partner życiowy } \\
\text { b) dzieci } \\
\text { c) rodzice, teściowie } \\
\text { d) dziadkowie } \\
\text { e) dalsza rodzina } \\
\text { f) prowadzenie domu }\end{array}$ & $\begin{array}{r}31 \\
60 \\
2 \\
1 \\
3 \\
7\end{array}$ & $\begin{array}{r}12 \\
22 \\
2 \\
1 \\
2 \\
-\end{array}$ & $\begin{array}{l}8 \\
6 \\
2 \\
- \\
- \\
3\end{array}$ \\
\hline
\end{tabular}

Wiedza na temat kobiety wyłaniająca się z jej językowego obrazu funkcjonującego w trzech wybranych periodykach skupiona jest na tym, co rejestruje potoczna świadomość ludzi. Podlega też takiemu rodzajowi kategoryzacji, który jest najistotniejszy dla twórców tych czasopism. Co za tym idzie, taki właśnie językowy obraz kobiety zostaje uwewnętrzniony przez czytelników (zwłaszcza czytelniczki) tych periodyków. Media, pełniąc swą funkcję perswazyjna, wpływają z całą pewnością na nasz sposób widzenia świata, narzucając nam - w pewnym zakresie - model postrzegania i kategoryzacji różnorakich zjawisk. Językowy obraz kobiety zostaje niejako dobrany do charakteru pisma. Musi być na tyle bliski czytelniczce, by ta zechciała określone czasopismo nabyć. Winien być też nieco odległy i niedostępny, by owa czytelniczka, chcąc mu dorównać, musiała korzystać z porad serwowanych przez periodyk. Redakcje sugerują swym odbiorcom określony obraz świata i tym samym wpływają na kształtowanie się grup czytelniczek. Podstawowym warunkiem przynależności do takich wspólnot jest preferowanie tych samych wartości i wyznawanie tych samych zasad oraz sposobów ich przestrzegania. Jedną ze strategii perswazyjnych jest bardzo atrakcyjne przedstawienie postulowanej wizji świata. Dzięki temu czytelnik podczas lektury czasopisma wprawiony jest w tak dobry nastrój, że sam pragnie przenieść się na stałe do tego lepszego, radośniejszego świata i zaakceptować wszystkie jego elementy4.

Uwarunkowania semantyczne leksemu kobieta mają zatem dwoisty charakter. Łączą się one, z jednej strony, z codziennym doświadczeniem, przed którym staje czytelniczka i które warunkuje jej myślenie o sobie i innych paniach, z drugiej zaś - ze sferą dążeń, zamierzeń i pragnień związanych z „by-

${ }^{4}$ Zob. W. Kajtoch, J. Kołodziej, P. Płaneta, Język czasopism dla młodzieży: świat, wartość, perswazja, w: Język w mediach masowych, red. J. Bralczyk, K. Mosiołek-Kłosińska, Warszawa 2000, s. 130-132. 
ciem kobietą". Do pierwszej z tych sfer egzystencji redakcja musi się dostosować, drugą może w dowolny niemalże sposób sterować, manipulować - nie tylko przez wskazywanie kierunków i trendów, ale także przez demonstrowanie wzorców negatywnych.

Dlatego też językowy obraz kobiety przedstawiony przez każde z trzech wybranych pism jest niejednorodny. Określa on bowiem różne bohaterki artykułów prasowych. Większość przypisywanych im cech jest koherentna. Cechy te - przez swoją spójność - wyznaczają wzorzec preferowany przez daną redakcję. Poniżej przedstawiam tylko te cechy, które składając się na pewną całość, mogą charakteryzować jedną kobietę. Zdaję sobie przy tym sprawę z tego, że w ten sposób oddalam się w pewnym stopniu od zasad tworzenia definicji kognitywnej. Notuje ona bowiem wszelkie cechy przedmiotu, zarówno te „wystarczające” (utożsamiające definiowane znaczenie ze znaczeniami zbliżonymi do niego) oraz „konieczne” (służące odróżnieniu opisywanego desygnatu od reszty świata), jak i te typowe, relewantne z punktu widzenia użycia wyrazu w tekstach językowych oraz jego stosunku do innych wyrazów języka ${ }^{5}$. Nie istnieje jednak żadna definicja, która jako cechy definiowanego przedmiotu wskazywałaby atrybuty sprzeczne. Tymczasem w zgromadzonym przeze mnie materiale poza przeważającymi elementami, które współtworzą preferowany przez czasopismo model „bycia kobietą, pojawiają się także by tak rzec - antywzorce, dlatego koniecznym zabiegiem jest selekcja. Sądzę bowiem, że tylko pomijając rażące niekoherencje, unikając mechanicznego podejścia do badanego materiału, można pokazać typowy obraz kobiety zawarty w każdym z tych czasopism.

Niemalże jak truizm zabrzmi stwierdzenie, że owa typowość jest zorientowana podmiotowo. W ten sposób jednak wyraża się istota problemu. Każde z pism postrzega kobietę inaczej, w inny sposób ją prezentuje i do innych postaw ją skłania. Niektóre jej cechy są zatem celowo uwydatnione, inne zaś pomniejszone lub ukryte i przemilczane. Słowa przechodzą w ten sposób przez specyficzny filtr, który przepuszcza tylko preferowane przez redakcję nazwy cech kobiety. Równie skutecznym zabiegiem perswazyjnym jest budowanie wzorców negatywnych. Mają one, co prawda, charakter marginalny (to drugi argument przemawiający za pominięciem tych elementów w moim artykule), jednak wzmacniają siłę oddziaływania modelu „,bycia kobietą” preferowanego przez czasopismo. Jeśli w obrębie tego dominującego modelu znajduje się

${ }^{5}$ Zob. J. Bartmiński, Podstawy lingwistycznych badań nad stereotypem - na przykładzie stereotypu matki, w: Stereotyp jako przedmiot lingwistyki. Teoria, metodologia, analizy empiryczne), red. J. Anusiewicz, J. Bartmiński, Wrocław 1998, Język a Kultura, t. 12, s. 63-83. Zob. także: J. Bartmiński, Językowe podstawy obrazu świata, Lublin 2006, s. 35-51 oraz J.D. Apresjan, Definiowanie znaczeń leksykalnych jako zagadnienie semantyki teoretycznej, w: Semantyka i stownik, red. A. Wierzbicka, Wrocław 1972, s. 39-75. 
wizja kobiety eleganckiej, zadbanej i wysportowanej, to potencjalnym antywzorcem będzie obraz kobiety otyłej, zaniedbanej i źle ubranej. W materiale oba wizerunki znajdą tekstowe potwierdzenie, jednak tylko jeden z nich odzwierciedla faktyczny obraz kobiety wspólny czytelniczkom, a kształtowany przez redakcję. Wzorzec negatywny wzmacnia jedynie ów dominujący model „bycia kobietą".

Przyjrzyjmy się zatem bliżej temu dominującemu modelowi.

Kobieta „Zwierciadła” została scharakteryzowana najdokładniej. Opisywany leksem pojawił się w tym miesięczniku aż 801 razy. $Z$ tego aż 192 jego użycia przypadły na profil szósty - „,echy i procesy psychiczne, postawa kobiety wobec otoczenia”. Nie jest to oczywiście przypadek. Charakteryzowana kobieta zwraca bowiem bardzo dużą uwagę na swą sferę psychiczną i rozwój duchowy.

Kobieta „Zwierciadła” ma najczęściej wyższe wykształcenie. Jej wiek przekracza zwykle trzydzieści lat:

Po 35. roku życia kobieta bardziej dba o siebie, dłużej zastanawia się nad wyborem odpowiednich kosmetyków i częściej odwiedza salony piękności. (Z 04/2007 53)

Jednak zazwyczaj pierwsze objawy skóry naczynioruchowej stają się widoczne u kobiet około 30. roku życia. (Z 01/2008 16)

Do swojego ciała podchodzi z szacunkiem. Jest ono dla niej atrybutem, atutem, którym można się pochwalić:

Pamiętaj: piersi to jeden z największych atrybutów kobiety [...]. (Z 04/2007 91)

Ciało informuje też o stanie, w którym znajduje się obecnie wnętrze kobiety:

Także regularne rysy, proporcjonalna sylwetka wskazują na silny organizm, który był w stanie zainwestować w symetrię. Np. nie bez powodu podobają nam się kobiety o symetrycznych piersiach. (Z 04/2007 75)

Podobnie kobiety o wąskiej talii. [Są bardziej płodne i przez to podobają się mężczyznom - M.S.R.] (Z 04/2007 75)

${ }^{6}$ Przyjęłam następujący sposób oznaczania cytatów: litera Z oznacza „Zwierciadło”, C „Cosmopolitan”, P - „Przyjaciółkę”; dalej podaję numer i rok wydania oraz stronę, na której znajduje się wynotowany fragment. 
Ciało stanowi jednak zawsze jedynie dodatek do osobowości. Kobieta „Zwierciadła” zawsze wybiera strój dopasowany do swoich potrzeb i sylwetki:

Nowe biustonosze i majteczki dostosowano do różnych typów kobiecego ciała, dzięki czemu każda kobieta bez trudu znajdzie model, który idealnie sprawdzi się podczas jej treningu. (Z 04/2007 91)

Jest piękna. Jej atrakcyjność zwiększa poczucie własnej wartości i pewność siebie:

Z chłopczycy przemieniłam się w młodą kobietę pewną swej urody, bo okazało się, że do twarzy mi w takich kobiecych ciuszkach. (Z 05/2007 22)

Z dużą ostrożnością podchodzi ona do środków higieny osobistej. Dokładnie przygląda się kosmetykom, których używa. Nigdy nie kupuje ich przypadkowo. Ufa tylko sprawdzonym markom. Śledzi ich skład chemiczny i zastanawia się nad doborem takich, które odpowiadałyby jak najdokładniej jej potrzebom:

Kiedy przeczytałam, że kobieta codziennie nakłada na skórę około 175 związków chemicznych, postanowiłam lepiej przyjrzeć się kosmetykom. (Z 08/2007 138)

Przełamuje stereotypy, ma w sobie tyle odwagi, by łamać zastane normy obyczajowe. Nie zgadza się ze społecznym nakazem powoływania na świat potomstwa. Chce sama decydować o swoim macierzyństwie:

Bardzo prawdopodobne, że orędownicy upokarzającego kobiety przymusu rodzenia nie doświadczyli w dzieciństwie matczynego ciepła, troski i miłości. (Z 08/2007 74)

Walczy też z popularnym sądem, jakoby kobieta w ciąży była zawsze szczęśliwa i pogodna. Tak samo jak w każdym innym momencie życia daje sobie prawo do odczuwania sprzecznych emocji:

Kobiety jednak mają prawo odczuwać w ciąży tyle samo sprzecznych emocji co w innych sytuacjach życiowych, które są dla nich wyzwaniem. (Z 08/2007 54)

Poród traktuje jak przeżycie metafizyczne, ma świadomość powagi i niezwykłości cudu narodzin, który dokonuje się na jej oczach: 
Na ile dzisiaj, my, kobiety, potrafimy znaleźć w sobie wiarę we własne możliwości i wewnętrzną siłę, by właśnie tak [jako duchową przemianę - M.S.R.] go [poród M.S.R.] przeżyć? (Z 08/2007 54)

Kobieta „Zwierciadła” miewa zmienne nastroje. Nie są jej obce zły humor czy nawet depresja, ani też emocje bliskie euforii. Można zresztą powiedzieć, że w jej życiu radość ma dwojaki charakter. Poza tą codzienną, wywołaną mniejszymi lub większymi sukcesami czy osiagnnięciami, pojawia się jeszcze inny rodzaj tego uczucia - radość z bycia kobietą:

Nowa sytuacja daje jej [kobiecie wyzwolonej spod działania męża tyrana-M.S.R.] takie możliwości, ale najpierw musi się spotkać z [...] przekonaniem, że można [...] czerpać radość i przyjemność z bycia kobietą. (Z 08/2007 29)

Wśród swoich marzeń za najważniejsze uznaje kobieta-bohaterka to o spełnionej miłości. Śni o miłości idealnej:

Najważniejsze marzenie każdej kobiety, czyli marzenie o miłości, mnie spełniło się stosunkowo wcześnie - mężczyznę mojego życia spotkałam już w szkole. (Z 08/2007 51)

[...] marzymy o kobietach, o mężczyznach, którzy pozwolą nam czerpać z życia to, czego pragniemy. (Z 05/2007 29)

Jest okrutnie rozczarowana, jeśli takiej miłości nie znajduje. Chce mieć bowiem partnera, który zapewni jej radość życia, pomocną dłoń i uśmiech na co dzień. Pragnie być rozumiana, kochana i szanowana.

Skrupulatnie analizuje swą rolę w społeczeństwie oraz w rodzinie:

Kobiety nie uświadamiają sobie, jak łatwo zgadzają się na narzuconą im od stuleci rolę [...]. (Z 08/2007 80)

Przygląda się sobie i porównuje swój świat z tym, który jest udziałem jej znajomych:

Przyglądam się moim koleżankom, kobietom aktywnym, kobietom świadomym. (Z 04/2007 6)

Ma świadomość swojej niezależności. Nie odczuwa potrzeby tłumaczenia się otoczeniu z tego, co robi, a przed czym się wzbrania:

Chodzi o to, by kobiety nie thumaczyły się z tego, co wybierają. (Z 08/2007 80) 
Aktywnie szuka nowych dróg, którymi mogłaby podążyć. Ma niezaspokojoną potrzebę ciagłego rozwoju duchowego. Swoją postawą zachęca też innych do zmian:

Świetne są kobiety z wizją, pomysłem na siebie, poszukujące. (Z 08/2007 106)

W tym kontekście kobiety to siła wstępująca, rewolucyjna. (Z 06/2007 67)

Zdarza jej się odczuwać zniechęcenie i przemęczenie. Sięga wówczas do wewnętrznych pokładów energii oraz siły, które pozwalają jej nie myśleć o złych chwilach:

I znów opowieść o silnej kobiecie i babci w jednej osobie. (Z 09/2007 100)

Przyznała pani, ze życie dziewczyny z okładki nie ułożyło się tak, jak pani sobie wymarzyła, ale dzisiaj spotykam pełną energii uśmiechniętą kobietę... (Z 05/ 2007 89)

Dla nastolatki była uosobieniem silnej, wyzwolonej kobiety. (Z 03/2007 38)

Dostrzega dyskryminację swojej płci. Chce działać na rzecz równouprawnienia obu płci tak, by kobiety mogły decydować o sobie same:

Dyskryminacja kobiet jest faktem, jednak ciagle mało uświadamianym, dlatego godzimy się na nią tak łatwo. (Z 08/2007 80)

O to, żeby nie było przymusów, żeby można było iść w lewo albo w prawo, ożenić się z tą kobietą albo wyjść za nie tego mężczyznę, którego nam rodzice przeznaczyli. (Z 04/2007 30)

Uważa, że dyskryminacja kobiet na rynku pracy nadal trwa. Nie zgadza się z nią, walczy o jej zniesienie:

O tym, jak trudno jest kobiecie awansować, jak dyskryminują ją mężczyźni. (Z 07/2007 90)

Kobieta „Zwierciadła” czuje się w pełni wartościowa, gdy zostaje mamą. Jeśli macierzyństwo z jakiegoś powodu ją ominie, traci poczucie własnej wartości. Jednocześnie opisywana osoba ubolewa nad faktem społecznego odrzucenia kobiet, które wybrały robienie kariery w zamian za rezygnację z macie- 
rzyństwa. Nie może się pogodzić z tym, że kobiety muszą w ogóle przed takim wyborem stawać:

[...] kobieta, która świadomie rezygnuje z macierzyństwa na rzecz rozwoju i kariery, spotyka się z oskarżeniem o egoizm. (Z 08/2007 73)

[...] tradycyjny system myślenia sprawia, że kobiety stają przed alternatywą: albo zawodowe spełnienie i niezależność, albo poświęcenie, pieluchy, gary i uzależnienie od partnera. (Z 08/2007 73)

Swoją pracę uznaje za wyzwanie. Chcąc mu jak najlepiej podołać, jest w stosunku do siebie bardzo wymagająca:

Kobiety robiące karierę stawiają sobie poprzeczkę bardzo wysoko. (Z 05/2007 67)

Ma wiele wrodzonych talentów: jest znakomitą negocjatorką, a dzięki intuicji inwestycje, którymi kieruje, zawsze przynoszą niebywałe zyski:

[...] kobiety są rewelacyjnymi negocjatorkami. (Z 05/2007 68)

[...] kobiety mają w inwestowaniu więcej szczęścia. (Z 04/2007 162)

Kobieta prezentowana na łamach „Zwierciadła” odczuwa potrzebę wspólnoty z innymi kobietami. Chce się z nimi jak najczęściej spotykać. Wie, że ta wspólnota jest im nawzajem potrzebna. Ma świadomość płynącej z niej siły. W trudnych sytuacjach życiowych pomagają jej inne, zgromadzone w owej wspólnocie, przedstawicielki płci pięknej:

Chcemy spotykać się we Wrocławiu, w Zielonej Górze, w Warszawie i wszędzie tam, gdzie kobiety nie boją się być razem. (Z 04/2007 39)

Kobiety potrzebują spotkań z innymi kobietami - dlatego powstał Klub Zwierciadła. (Z 04/2007 39)

Kreowana przez „Zwierciadło” bohaterka zdaje sobie sprawę z solidarności kobiet. Zawsze liczy na ich wsparcie. A w grupie kobiety potrafią być na tyle silne, by także politycznie walczyć o prawo do samostanowienia. Stąd pomysł stworzenia partii kobiet:

Cieszę się, że nadszedł czas, kiedy kobiety mogą zorganizować się razem, choćby tworząc Partię Kobiet. (Z 05/2007 20) 
[...] pora stworzyć partię, która zrzeszyłaby kobiety aktywne, mądre i chcące walczyć o wspólne sprawy. (Z 05/2007 20)

Rozpatrując sferę erotyczną opisywanego modelu kobiety, należy zauważyć, że dominuje tu wizja przedstawicielki płci pięknej jako obiektu pożądania mężczyzn. Kobieta „Zwierciadła” wierzy, że tak samo jak mężczyzna ma prawo do satysfakcji seksualnej. Od tego, czy ją uzyska, uzależnione jest w pewnym stopniu - szczęście związku:

Im więcej radości czerpie kobieta z satysfakcjonującego seksu z partnerem, tym bardziej udany będzie ich związek. (Z 04/2007 167)

Jest niezależna, w niczym nie ustępuje swojemu mężczyźnie. W grze miłosnej jest równorzędnym partnerem. Ma wygórowane wymagania, zna bowiem swoją wartość:

Kobiety w tym przodują. [W wygórowanych wymaganiach względem swych parterów - M.S.R.] (Z 04/2007 72)

Kobieta może być przepełniona bólem, żalem z powodu utraty męża, jego zdrady lub nieporozumień, do jakich doszło między nimi. Potrafi odnaleźć w sobie siłę i odejść od mężczyzny, gdy poczuje się zmuszona do tego, nawet jeśli ich związek trwał wiele lat. Nie pozwala się ranić:

Miesiąc temu rozmawialiśmy o kobiecie, która po 15 latach małżeństwa zdecydowała się odejść od męża. (Z 04/2007 82)

Kobieta w „Zwierciadle” jest ukazana jako istota samowystarczalna. Mężczyzna nie jest jej potrzebny nawet do prokreacji czy współdziałania w procesie wychowywania dzieci:

Nową rzeczą jest to, że kobieta może mieć dziecko bez mężczyzny u swego boku. (Z 04/2007 72).

Jeśli dotąd porządna kobieta mogła mieć tylko dziecko z mężczyzną, który ją do tego uprawnił, nic dziwnego, że może chcieć mieć to dziecko bez niego, skoro istnieje taka możliwość. (Z 04/207 72)

Kobieta, którą kreuje się w „Zwierciadle”, rozważa i planuje swoje macierzyństwo, uświadamia sobie grożące jej niebezpieczeństwa, zdaje też sobie sprawę z powołania społecznego i wyzwania egzystencjalnego, jakim jest sprowadzenie dziecka na świat: 
[...] już jako dorosła kobieta zrozumiałam, jak ważne dla świata i dla mnie samej jest to, że kobiety rodzą i wychowują dzieci. (Z 08/2007 75)

Czuje się rozdarta pomiędzy dwiema drogami życiowymi. Zastanawia się nad wyborem: ,albo dzieci, albo kariera”:

W zasadzie nie ma dobrego wyjścia: rola tradycyjna, gdy kobieta prowadzi dom, rodzi dzieci i je wychowuje, jest odarta z prestiżu [...]. (Z 08/2007 73)

Zdaje sobie jednak sprawę z tego, że kobieta, która rezygnuje z macierzyństwa na rzecz rozwoju zawodowego jest społecznie odrzucana. Stara się być jak najlepszą matką dla swoich pociech. Wie bowiem, jak ważną rolę w jej dorosłym życiu odegrała matka:

Na pewno wiele zawdzięczam mamie, bardzo mądrej kobiecie, z którą rozmawiałam na różne tematy, między innymi na temat przemijania. (Z 05/2007 40)

Kobieta „Przyjaciółki” najpełniej scharakteryzowana zostaje w ekscerptach, które przyporządkowałam do profilu piątego - „procesy oraz czynności fizyczne i fizjologiczne". Należy do niego aż 59 ekscerptów poświęconych wskazanej tematyce. Ogółem w tygodniku tym odnalazłam najmniej poświadczeń leksemu kobieta (zaledwie 297), o czym wspominałam już wcześniej. Istotę dorosłą płci żeńskiej w „Przyjaciółce” określa się bowiem głównie mianem pani.

Kobieta przedstawiana na łamach tego periodyku ma najczęściej ponad trzydzieści lat:

Zdaniem 36 proc. ankietowanych kobieta jest najbardziej atrakcyjna po trzydziestce, ale aż 25 proc. uważa, że po czterdziestce. (P 35/2007 18)

Kobieta ta bacznie obserwuje swe ciało, by dobrać strój stosowny do jego budowy. Zdaje sobie sprawę z czekającego ją i jej strój osądu społecznego. Wie, że postrzeganie jej osoby przez otoczenie zmienia się w zależności od tego, co na siebie włoży, potrafi też tym świadomie manipulować:

Kobiety, które mają na sobie coś czerwonego, są postrzegane jako pewne siebie, gotowe do działania, ale także zmysłowe i seksowne. (P 50/51/2006 12)

Kobieta „Przyjaciółki”, podobnie jak opisywana wcześniej kobieta „Zwierciadła", zwraca uwagę na kosmetyki sprawdzone. Czyni to z przyzwyczajenia 
i przekonania, że to, co dobre - jest ponadczasowe. Wybiera zatem marki, których używała jej mama, a nawet babka:

Są jak delikatny złoty łańcuszek - pasują do każdej kobiety i nigdy nie wychodzą z mody. [Mowa o niektórych kosmetykach - M.S.R.] (P 19/2007 15)

Kolejne pokolenia kobiet sięgają po ponadczasowe hity [kosmetyczne - M.S.R.]. (P 19/2007 15)

Dba, by zarówno zabiegi kosmetyczne, jak i higiena osobista wpływały na jej zdrowie oraz dobre samopoczucie.

Żywo interesuje się swoją dietą, chce wiedzieć, czy dostarcza organizmowi wszystkich składników odżywczych niezbędnych do prawidłowego funkcjonowania:

Dieta przeciętnego mieszkańca Polski - zarówno kobiet, jak i mężczyzn nie dostarcza wystarczającej dawki selenu. (P 50/51/2006 41)

Pilnie obserwuje swoją sylwetkę, by jak najszybciej przeciwdziałać wszelkim odchyleniom od przyjętej przez siebie normy. Jednak zawsze ostrożnie omija niebezpieczne dla zdrowia głodówki.

Kobieta „Przyjaciółki”, podobnie jak kobieta „Zwierciadła”, marzy o przystojnym, rozumiejącym ją i wrażliwym mężczyźnie:

Przystojny, wrażliwy [...] - przecież o takim mężczyźnie kobiety marzą! (P 40/ 2007 34)

Kobieta ta jawi się nam jako odoba rozsądna, doświadczona, która w związku z tym, że sama w życiu wyszła obronną ręką z wielu opresji, potrafi i bardzo chce pomagać innym - zwłaszcza przedstawicielkom płci pięknej:

Są sprawy, w których nikt nie doradzi nam lepiej niż inna, doświadczona kobieta. (P 49/2007 24)

Jest aktywna, choć w sposób nieco inny niż kobieta „Zwierciadła”. Jej aktywność oznacza pracowitość oraz łączenie obowiązków zawodowych z zajmowaniem się domem. Nie waha się nazwać siebie „kobietą pracującą” lub „kobietą czynu”:

Kobieta czynu [tytuł podrozdziału - M.S.R.] (P 30/2007 49)

Jestem kobietą pracującą. (P 40/2007 14) 
Ponieważ dzieci są dla niej najważniejsze, potrzebuje pewności, że podczas gdy ona pracuje, jej pociechy są pod dobrą opieką i nic im nie zagraża. To rodzina, a nie praca, stanowi jej priorytet życiowy, dlatego często po urodzeniu dziecka rezygnuje z życia zawodowego:

Kobieta chciałaby mieć pewność, że malec, w czasie gdy ona pracuje, jest dopilnowany, nakarmiony, szczę́liwy. (P 40/2007 18)

Dlatego tylko 23 proc. kobiet wraca do pracy tuż po urlopie macierzyńskim. [Bo trudno im rozstać się z dzieckiem - M.S.R.] (P 40/2007 16)

Kobieta „Przyjaciółki” spogląda na swoje zarobki z punktu widzenia matki, która pragnie mieć tyle pieniędzy, by nie musieć pracować i móc zostać w domu ze swoją pociechą. Pracę traktuje zatem jako konieczność, która nie powinna kolidować z opieką nad dziećmi:

[...] 60 proc. kobiet, jeśliby tylko mogło sobie na to pozwolić, chętnie zostałoby w domu z dzieckiem. (P 40/2007 17)

To one [pieniądze - M.S.R.] motywują 55 proc. kobiet do porzucenia domowych pieleszy. (P 40/2007 17)

Kobieta kreowana w „Przyjaciólce” jest utożsamiana z żoną lub przynajmniej partnerką życiową - stały związek, w którym pozostaje, wyznacza jej przestrzeń egzystencjalna, porządkuje życie i warunkuje najbardziej podstawowe aktywności. Jest on także jedyną możliwą drogą do szczęścia i spełnienia.

Kobieta „Cosmopolitan” została wyraziście określona - badany leksem wystapił aż w 534 ekscerptach. Najwięcej spośród nich (aż 173) znalazło się w profilu jedenastym - „miłość, seks, intymność”. Jest to bowiem tematyka istotna dla życia kobiety „Cosmopolitan” - można nawet powiedzieć, że stanowi jeden z najistotniejszych elementów jej egzystencji.

Ta młoda, zazwyczaj dwudziestoparoletnia kobieta ma świadomość wyższości nad płcią przeciwną:

Jeśli jesteś kobietą sukcesu i chcesz poznać faceta na swoim poziomie, ups, zdaje się, że możesz mieć duży problem. (C 08/2008 89)

Chce się mężczyznom podobać, ale głównie po to, by móc ich zdobywać. Jej związki z płcią przeciwną polegają na prowadzeniu gry-walki. Pragnie zbliżać się do mężczyzn, by ich pokonywać. 
Aby zdobyć swój cel, musi wyglądać nienagannie. Dlatego bardzo dba o ciało i odpowiednio dobrany strój. Wie, że ten duet jest w stanie zapewnić jej zwycięstwo nad mężczyznami:

Większość facetów na widok kobiety w pikantnej bieliźnie ma stan przedzawałowy [...]. (C 10/2007 78)

Obsesyjnie próbuje schudnąć, by być jeszcze bardziej ponętną dla ,facetów”:

$70 \%$ kobiet ma co roku takie samo noworoczne postanowienie: schudnąć! (C $01 / 2008$ 10)

W tekstach czasopisma widoczne jest zjawisko, które można by określić mianem mechanizmu ,spojrzenia męskim okiem”:

Mężczyźni powiedzieli nam to wprost: uwielbiaja, gdy kobiety nie wstydzą się swego ciała. (C 09/2007 61)

Faceci uwielbiają kobiety, które potrafią się bawić w łóżku. (C 09/2007 60)

To przedstawiciele płci przeciwnej mają kobietę „Cosmopolitan” oceniać, to im ma się podobać, to nad nimi ma zwyciężać.

Kobieta traktuje swą urodę jak lep, na który może złapać wymarzonego mężczyznę. Dlatego wszystko to, co czyni ze swym wyglądem, uzależnia od aprobaty rzeczywistego lub potencjalnego partnera. Każda zmiana musi najpierw zostać zaakceptowana przez niego.

Tak więc kobieta „Cosmopolitan” do oceny swej urody potrzebuje mężczyzny. Potrafi czuć się piękna tylko wówczas, gdy zobaczy zachwyt w jego oczach. Jej samej uroda i dobry wygląd nie są potrzebne. Pragnie je zachować jedynie dla przedstawicieli płci brzydkiej:

W jego obecności kobieta czuje się delikatnie podrywana, w tak miły sposób, że... czuje się piękna w jego oczach. (C 08/2007 13)

Skoro związek, który ze swym mężczyzną tworzy, jest walką, dozwolone są w niej wszelkie środki prowadzące do wygranej. Podczas kłótni wykorzystuje przeróżne sposoby, aby zwyciężyć. Jednym z nich jest płacz:

Znam kobiety, które wykorzystują łzy jako atut - gdy np. kłócą się z facetem. (C 05/2007 34) 
Przemilcza swe potrzeby w związku. Nie chce, aby partner pomyślał, że jest rozkapryszona i przesadnie wymagająca. To świadczyłoby o jej słabości:

Wiele kobiet przemilcza swoje potrzeby - że marzą o masażu stóp czy chwili samotności - bo nie chcą uchodzić za zbyt wymagające. (C 08/2007 48)

Żyje w przekonaniu, że tylko przebojowością i inicjacją współżycia seksualnego jest w stanie doprowadzić mężczyzn do zadowolenia, a siebie do satysfakcji seksualnej i - co wydaje się w jakiś sposób z tą satysfakcją związane - niezachwianego przekonania o własnej sile, władzy i przewadze nad partnerem:

Mężczyzna jest zachwycony, kiedy kobieta inicjuje seks. (C 09/2007 60)

55 proc. facetów najbardziej kręci, kiedy to kobieta inicjuje igraszki. (C 07/ $200766)$

Nie planuje zakładać rodziny. Ceni swą niezależność. Macierzyństwo to bardzo odległy plan życiowy, który może się nigdy nie zrealizować. Żal jej straty dobrej posady i świetnej figury:

Jednym z powodów błyskawicznego powrotu do superfigury jest to, że kobiety „pilnują się” w czasie całej ciąży. (C 02/2007 71)

Nie podoba jej się także konieczność przerwy w życiu erotycznym:

Po co kobiecie w zaawansowanej ciąży sexy triki, skoro nie może nawet wdrapać się na swojego mężczyznę? (C 02/2007 6)

Dlatego kobieta „Cosmopolitan” stara się nie zajść w ciążę zbyt szybko. Czasami w ogóle nie ma potomstwa. Stając przed wyborem „dziecko czy kariera", zawsze wybiera to drugie. Wszak z ciążą można poczekać - przynajmniej do czterdziestki:

Matka natura niestety nie gra w tym przypadku fair: tylko my, kobiety, mamy limit czasowy na urodzenie dziecka - do późnej czterdziestki. (C 08/2007 91)

Jej wielkim pragnieniem życiowym jest zdobycie dobrej, wysoko płatnej pracy. Marzy też o zaspokojeniu swoich pragnień i potrzeb seksualnych:

Jako młoda kobieta wciąż czegoś szukałam, nie wiedziałam, czego chcę, jak mam zaspokoić swoje potrzeby, pragnienia. (C 04/2007 8) 
Wykonanie tych postawionych przed sobą zadań doprowadzi ją do pełnej, tak pożądanej przez nią, niezależności.

Od tego, czy osiagnie obydwa cele, uzależnia poczucie własnej wartości oraz godności. To właśnie doświadczenia z mężczyznami wskazują na to, jaką jest osobą. Oni są bowiem dla niej najistotniejszymi sędziami w życiu:

W tym wieku samoocena kobiety zależy od jej doświadczeń z mężczyznami, a jednym ze sposobów na uporanie się $\mathrm{z}$ tym towarzyskim stresem jest zapijanie go lub zagłuszanie narkotykami [...]. (C 11/2007 91)

Kobieta opisywana na łamach „Cosmopolitan” prowadzi bujne życie erotyczne. Nie dobiera starannie znajomych, nie stroni od wszelkiego rodzaju używek. $Z$ wymienionych powodów często przebywa w gronie nieznanych sobie osób. Jeśli połączyć to z predylekcją do sięgania po różnego rodzaju używki, łatwo zauważyć niebezpieczeństwa, które mogąjej zagrażać. Do nich należy współżycie seksualne z obcymi mężczyznami odbywające się zazwyczaj pod wpływem alkoholu:

Toksykolog powołany przez obronę stwierdził, że poziom alkoholu we krwi młodej kobiety wskazywał, iż znajdowała się w stanie upojenia, co oznacza, że mogła nie być zdolna, by wyrazić zgodę na seks. (C 11/2007 91)

Kobieta „Cosmopolitan” bierze udział w akcjach społecznych, które mają na celu wyłonienie silnych, aktywnych i współdziałających kobiet:

Na początku roku 33-letnia Eva została laureatką akcji, organizowanej przez amerykańską edycję Cosmo [...], której odpowiednikiem są nasze Mocne Strony Kobiety. (C 04/2007 12)

Ale się działo... Relacja z wielkiego finału akcji Mocne Strony Kobiety. (C 02/ 2007 2)

Wierzy w moc drzemiącą w przedstawicielkach jej płci. Pragnie eksponować tę siłę - jak najczęściej wydobywać ją na światło dzienne.

Ceni swych rodziców. Wie, że wzorce i ideały, które wyniosła z domu rodzinnego, będą miały wpływ na jej późniejsze relacje z mężczyznami:

Jedyny problem z tym, że niekiedy kobiety, które miały zaburzone relacje z ojcem, powielają toksyczny wzorzec w relacjach z partnerem. (C 07/2007 66)

Zamykając powyższe rozważania - choć podsumowanie tak wielkiej rozmaitości zjawisk wydaje się niemal niemożliwe - stwierdzić należy, że kobiety 
prezentowane na łamach „Zwierciadła” i „Przyjaciółki” są w pewnym stopniu do siebie podobne, w przeciwieństwie do kobiety „Cosmopolitan”, choć zauważalne są też podobieństwa łączące wszystkie trzy przedstawione tu językowe obrazy kobiety. Bohaterki „Cosmopolitan”, „Przyjaciółki” i ,Zwierciadła” są zainteresowane swoim zdrowiem oraz wyglądem zewnętrznym. Chcą być piękne, jednocześnie zaś pragna, by ceniono je nie tylko za urodę. Zdobyły wykształcenie i pracują zawodowo. Na co dzień stykają się z rozmaitymi problemami związanymi z życiem społecznym. Doświadczają przemocy fizycznej i psychicznej, stykają się z nietolerancją i dyskryminacją. Wszystkie - choć każda na swój sposób - poszukują bezpieczeństwa i - przede wszystkim - miłości. Są heteroseksualne i choć każda z nich ma inną wizję relacji z mężczyzną, wszystkie właśnie w związku z przedstawicielem płci przeciwnej upatrują naturalnego porządku swojej egzystencji. Dla każdej z nich istotnym elementem tego porządku jest życie erotyczne oraz konieczność podjęcia decyzji związanej z macierzyństwem.

Im wnikliwiej przyglądamy się jednak owym trzem językowym obrazom kobiety, tym łatwiej zauważamy fakt, że bohaterki „Zwierciadła” i „Przyjaciółki” są sobie w pewnej mierze bliskie. Dla obu istotna jest rodzina, choć w nieco inny sposób. Podczas gdy pierwsza z nich prowadzi bujne życie zawodowe i rodziny może pragnąć jedynie potencjalnie, druga uwielbia pobyt w zaciszu domowym, a pracę zawodową traktuje jako źródło dochodu niezbędnego do przetrwania. Obie interesują się własnym zdrowiem. Kobieta „Zwierciadła” intensywniej jednak niż o ciało dba o psychikę i emocje. Jest odważniejsza w łamaniu stereotypów niż osoba kreowana na kartach „Przyjaciółki. Chce zmieniać i dementować krzywdzące kobietę opinie oraz przesądy. Tymczasem bohaterka „Przyjaciółki” w ogóle taką działalnością nie jest zainteresowana. Ma mnóstwo domowych i zawodowych obowiązków. Rzadko kiedy zwraca uwagę na sprawy globalne, takie jak na przykład dyskryminacja płci pięknej na rynku pracy. Bardziej interesuja ją porady dotyczące powrotu kobiety do pracy po urlopie macierzyńskim.

Co innego zaś kobieta „Cosmopolitan”. Można powiedzieć, że krąg jej zainteresowań wyznacza bujne życie towarzyskie i erotyczne. Generalizujący charakter tego sądu jest w pewnej mierze krzywdzący, jednak nie zmienia to faktu, że tematyka związana z rozkoszami spod znaku Wenus odgrywa dla kobiety prezentowanej na łamach „Cosmopolitan” najistotniejszą rolę. Dla zaznania tych rozkoszy konieczna jest interakcja. Dlatego też drugim - równie istotnym - elementem kształtującym tematykę tego czasopisma jest wizja partnera jako przeciwnika, z którym toczy się miłosną grę. Owa wizja partnera dopełnia główną sferę tematyczną „Cosmopolitan”. Można właściwie powiedzieć, że orbita ta w dużej mierze wpływa na każdy z profili językowego ob- 
razu kobiety prezentowanego w omawianym periodyku. Świetnych przykładów dostarczają tu rozmaite elementy, które współtworzą to, co powszechnie określa się mianem wyglądu zewnętrznego. Wszystkie te elementy w przypadku kobiety „Cosmopolitan” muszą być jak najbardziej efektowne. „Cosmodziewczyna" powinna zatem nie tylko modnie się ubierać, nie tylko nosić ekskluzywne dodatki i mieć ekstrawagancki makijaż, ale przede wszystkim być „sexy” - to znaczy tak kształtować wszystkie elementy swojego wyglądu zewnętrznego i zachowania, by pociagały mężczyzn i budziły zazdrość wśród innych przedstawicielek płci pięknej. Jednocześnie zaś w relacjach, które nawiązuje, podobnie jak w życiu zawodowym, winna za wszelką cenę starać się budować swoją niezależność, odrzucając przy tym perspektywę założenia rodziny, rodzenia dzieci, prowadzenia gospodarstwa domowego oraz podejmowania jakichkolwiek kroków zmierzających ku ustabilizowaniu sytuacji życiowej.

Jak zatem łatwo można zauważyć, na łamach każdego z omawianych czasopism kreuje się inny językowy obraz kobiety. Można powiedzieć, że uwewnętrznienie tego obrazu jest jednym z elementarnych „,ruchów recepcyjnych” zaprojektowanych na poziomie odbiorcy wirtualnego.

Mechanizm odbioru każdego z tych czasopism można by zatem opisać następująco: czytelniczka uznaje językowy obraz kobiety napotkany w danym periodyku (akt uznania zaprojektowany na poziomie czytelnika wirtualnego stanowi bowiem element niezbędny dla recepcji) i zaczyna kreować własną egzystencję tak, by niwelować niespójność między tym, jak faktycznie jest, a tym, jaka uznaje, że być powinna osoba określana leksemem kobieta.

Takie kierowanie procesem odbioru stanowi, jak należy sądzić, podstawową siłę perswazyjną omówionych tu czasopism kobiecych. Konsekwentnie forsują one niemalże ukonkretnione modele „bycia kobieta”, a działanie to znakomicie widoczne jest właśnie na poziomie językowego obrazu świata.

Nie twierdzę przy tym, że każde czasopismo i gazeta posługują się tym mechanizmem. Nie wyobrażam sobie zresztą, by na przykład ogólnopolskie dzienniki adresowane do ogromnego spektrum odbiorców miały możliwości takiego oddziaływania na swoich czytelników. Istnienia omówionej tu siły perswazyjnej należy poszukiwać jedynie w mediach o zawężonej grupie odbiorczej - czyli w takich, w których można sformułować w miarę szczegółowe założenie dotyczące rynkowego targetu i - co za tym idzie - personalizować, usubiektywniać poziom zakładanego odbiorcy tekstu. Prowadzę dalsze, szczegółowe badania z tego zakresu i już teraz mogę powiedzieć, że problematyka owego modelu perswazyjnego wyłaniającego się z kart pism kobiecych wydaje się ze względu na swą niejednorodność niezwykle ciekawa. 


\section{Magdalena Spychała-Reiss}

\section{A Linguistic Picture of a Woman in Women's Magazines (on the example of Zwierciadło, Cosmopolitan and Przyjaciótka)}

The article presents a linguistic picture of a woman shown in the contemporary women's magazines. The material studied has been derived from three women's magazines: Zwierciadło, Cosmopolitan and Przyjaciótka (specifically, from the issues published between December 2006 and February 2008). It has been limited to the lexeme woman; all its synonyms and paraphrases have been disregarded. In the material discussed, this word shows semantic relationships with a repetitive number of subjects. On the basis of observations the author has prepared a list of 12 profiles, which, in turn, got divided into subcategories - facets. The excerpts thus classified and grouped have revealed the fact that a linguistic picture of a woman differs, to some extent, in each of the studied periodicals, depending on the character of the magazine. Woman readers, while identifying themselves with this picture, form exclusive communicative and social communities.

Parallely, a linguistic picture of a woman in each of the magazines is not homogenous since it refers to different women. It contains all the attributes of the subject, both the "sufficient" ones (identifying the defined meaning with similar meanings) and the "indispensible" ones (differentiating the lexeme described from the rest of the world) as well as the "typical" ones, relevant from the point of view of the usage of the word in linguistic texts and its relation to other linguistic items. 